\title{
Prostate cancer cells at a therapeutic gunpoint of the autophagy process
}

\author{
Fabio Gabriele, Carolina Martinelli, Sergio Comincini \\ Department of Biology and Biotechnology, University of Pavia, Pavia 27100, Italy. \\ Correspondence to: Dr. Sergio Comincini, Department of Biology and Biotechnology, University of Pavia, Pavia 27100, Italy. \\ E-mail: sergio.comincini@unipv.it
}

How to cite this article: Gabriele F, Martinelli C, Comincini S. Prostate cancer cells at a therapeutic gunpoint of the autophagy process. J Cancer Metastasis Treat2018;4:17. http://dx.doi.org/10.20517/2394-4722.2018.06

Received: 24 Jan 2018 First Decision: 26 Feb 2018 Revised: 6 Mar 2018 Accepted: 26 Mar 2018 Published: 19 Apr 2018

Science Editors: Chun Hei Antonio Cheung, Lucio Miele Copy Editor: Jun-Yao Li Production Editor: Cai-Hong Wang

\begin{abstract}
In a normal prostate, the process of controling cell death is essential to maintain tissue homeostasis and its inhibition may lead to the development of cancer. Androgen receptor signaling plays pivotal roles in the prostate development and homeostasis as well as in the progression of prostate cancer. The main treatment for prostate cancer is a combination of androgen deprivation therapy (ADT) using anti-androgens and docetaxil administration. However, ADT eventually fails due to a pathological unbalance of cell death processes, in particular apoptosis and autophagy. As a result prostate tumors may re-grow and progress into the castration resistant stage. The role of autophagy in tumorigenesis is complex and it could be a double-edged sword process, as autophagy defects promote cancer progression in association with various dangerous cellular processes, while functional autophagy enables cancer cell survival under stress and likely contributes to the resistance of treatment. Autophagy is often impaired in prostate cancer, due to either activation of the Akt/mTOR pathway, which normally inhibits autophagy, or through allelic loss of Beclin-1 (BECN1), an essential autophagy gene. In particular, elucidating the interplay between autophagy and tumor cell metabolism will provide unique opportunities to identify new therapeutic targets and to develop synthetically lethal treatment strategies that preferentially target cancer cells, while sparing normal tissues.
\end{abstract}

Keywords: Prostate cancer, autophagy, androgen deprivation therapy, mTOR, autophagosome, LC3-II, Beclin-1

\section{PROSTATE CANCER INCIDENCE AND GENETICS}

Prostate cancer is a tumor that develops in the prostate, a gland in the male reproductive system. Most prostate cancers are slow growing but there are cases of aggressive forms. Tumor cells may metastasize from the prostate to other parts of the body, particularly the bones and lymph nodes. Prostate cancer may cause pain, difficulty in urinating, problems during sexual intercourse, or erectile dysfunction. In particular,

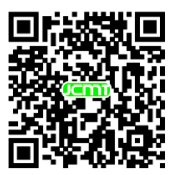


Table 1. Main genes involved in prostate cancer

\begin{tabular}{|c|c|c|}
\hline Gene & Full name & Function/references \\
\hline$B R C A 1$ & $\begin{array}{l}\text { Breast cancer susceptibility } \\
\text { protein type } 1\end{array}$ & DNA repair ${ }^{[/]}$ \\
\hline$B R C A 2$ & $\begin{array}{l}\text { Breast cancer susceptibility } \\
\text { protein type } 2\end{array}$ & DNA repair ${ }^{[7]}$ \\
\hline HPC1 & Hereditary prostate cancer & Prostate cancer susceptibility ribonuclease $\mathrm{L}^{[8]}$ \\
\hline$V D R$ & Vitamin D receptor & $\begin{array}{l}\text { Inhibition of cell growth, metastasis and angiogenesis; apoptosis modulation and cell } \\
\text { differentiation }^{[8]}\end{array}$ \\
\hline CD82 & Cluster of differentiation 82 & Metastasis suppressor attenuates the matrix adhesion ${ }^{[9]}$ \\
\hline PTEN & Phosphatase and tensin homolog & Tumor suppressor and cell cycle regulation ${ }^{[9]}$ \\
\hline$m T O R$ & Mammalian target of rapamycin & Key signaling pathway linked to tumorigenesis and resistance to therapy ${ }^{[10]}$ \\
\hline PSA & Prostate specific antigen & Dissolver of cervical mucus, allowing the entry of sperm in the uterus ${ }^{[11]}$ \\
\hline$B C L 2$ & B-cell lymphoma 2 & $\begin{array}{l}\text { Pro-survival protein associated with the development of androgen-independent } \\
\text { prostate cancer }{ }^{[12]}\end{array}$ \\
\hline MKI67 & Antigen $\mathrm{Ki}-67$ & Nuclear protein involved cell proliferation ${ }^{[13]}$ \\
\hline$E R K-5$ & Mitogen-actvated protein kinase 7 & $\begin{array}{l}\text { Signaling processes of various receptor molecules. In response to extracellular signals, } \\
\text { this kinase translocate to the nucleus, where it regulates gene expression and activates } \\
\text { different transcription factors }{ }^{[14]}\end{array}$ \\
\hline SP1 & Transcription factor Sp1 & $\begin{array}{l}\text { Involved in many cellular processes, including cell differentiation, growth, apoptosis, } \\
\text { immune responses, DNA damage, and chromatin remodeling }{ }^{[15]}\end{array}$ \\
\hline TPD52 & Tumor protein 52 & Unknown ${ }^{[16]}$ \\
\hline
\end{tabular}

prostate cancer tends to develop in men over the age of fifty ${ }^{[1]}$. Rates of detection of prostate cancers vary widely across the world, with South and East Asia detecting less frequently than in Europe and in the United States. Globally, it is the sixth leading cause of cancer-related death in men ${ }^{[2]}$. More than 200,000 new cases are estimated in the United States in 2013, with a mortality rates over per 10 cases. Moreover, there are different ways of classifying patients with prostate cancer: the tumor-node-metastases (TNM) classification of malignant tumors evaluates the extension of the tumor, the involvement of lymph nodes and the metastatic dissemination. The Gleason Grading system is additionally used to evaluate the prognosis of men with prostate cancer. A Gleason score is given to prostate cancer based upon its microscopic appearance: cancers with a higher Gleason score are more aggressive and have a worse prognosis ${ }^{[3,4]}$.

Many factors, including genetics and diet, have been implicated in the development of this cancer. As suggested by association studies, genetic background can contribute to prostate cancer risk with family, race, and specific gene variants. Men who have a first-degree relative (brother or father) with prostate cancer have twice the risk of developing the cancer, and those with two first-degree relatives affected have a fivefold greater risk compared with men with no family history ${ }^{[5]}$. Studies of twins in Scandinavia suggest that $40 \%$ of prostate cancer risk can be explained by inherited factors ${ }^{[6]}$.

A summary of the different genes implicated in prostate cancer are highlighted in Table $1^{[7-16]}$.

\section{METABOLISM AS A PRIVILEGED TARGET IN PROSTATE CANCER CELLS} Different metabolic targets and sub-targets in prostate cancer

The specific alterations in metabolic pathways observed in cancer cells confirm that tumors need unusual amounts of energy and biosynthetic precursors to survive and grow ${ }^{[17]}$.

However, the unique intermediary metabolism in prostate cancer cells is substantially different from that found in other cancer cell types ${ }^{[18]}$. In particular to satisfy the energy demand and to generate ATP, most cancer cells are mainly derive energy from aerobic glycolysis ${ }^{[19]}$. In androgen-dependent prostate cancer cells, Warburg ${ }^{[19]}$ has demonstrated that glucose does not play a major metabolic role because LNCaP cells, and androgen-sensitive human prostate adenocarcinoma cells ${ }^{[20]}$ widely employed in in vitro prostate cancer studies, can even grow in presence of low glucose concentrations ${ }^{[21]}$. Therefore, the metabolic state of prostate cancer cells is altered to satisfy the increased demand for energy that is required to support the 
stimulated protein synthesis; moreover, these cells also have an inefficient autophagy process due to reduced catabolism $^{[22]}$. The inhibition of glycolysis by the promoting some kind of metabolic stresses may be used to improve therapies. A novel therapeutic paradigm was the treatment introduced by DiPaola et al. ${ }^{[23]}$, using 2-Deoxy-D-glucose (2DG), an inhibitor of glycolysis and a glucose analogue that blocks the uptake of glucose and induced cytotoxicity and autophagy in different prostate cancer cells. It was, therefore, hypothesized that prostate cancer is metabolically fragile because of dependence on glycolysis and impaired autophagy.

Interestingly, altered lipid metabolism has also been demonstrated by multiple groups to play an important role in prostate cancer progression ${ }^{[24]}$. Fatty acid synthase (FAS), a rate-limiting enzyme in de novo lipogenesis, is frequently over-expressed in prostate cancers ${ }^{[25,26]}$. Correspondingly, pharmacological or molecular inhibition of either FAS or other lipogenic enzymes, like acetyl-coenzyme A carboxylase (ACC) and ATP citrate lyase (ACL), suppressed both in vitro and in vivo tumor growth ${ }^{[27,28]}$. FASs are also stimulated by androgen hormones as seen in LNCaP cell accumulation of lipid droplets (LDs) within the cytoplasm ${ }^{[29]}$ containing both triacylglycerols (TGs) and cholesterols, which are enveloped by a monolayer of phospholipids and associated proteins ${ }^{[30]}$. LDs can be metabolized by hormone-regulated cytosolic lipases that break down the TGs into fatty acids which are then utilized for $\beta$-oxidation ${ }^{[31]}$, but there is a second pathway involving lipolysis mediated by autophagy. Recently, Singh et al. ${ }^{[32]}$ reported that in rat hepatocytes, autophagosomes sequestered LDs and caused lysosomal lipolysis. An alternative pathway of lipolysis has been observed also in prostate cancer cells, further explaining how prostate cancer cells may adapt to survive in hostile environmental conditions ${ }^{[33]}$. Although androgens promote prostate cancer cell growth in part by increasing the expression of several of these lipogenic enzymes ${ }^{[24,34,35]}$, it is not known whether androgens may promote the formation of these lipid reservoirs by additional mechanisms that may also be critical for tumorigenesis ${ }^{[36]}$.

Statins (or HMG-CoA reductase inhibitors) are a class of drugs used to lower cholesterol levels by inhibiting the enzyme HMG-CoA reductase, which plays a central role in the production of cholesterol in the liver. Statins such as atorvastatin (ATO), in addition to their effects on cholesterol biosynthesis, have attracted considerable interest for their possible utility in cancer prevention and therapy ${ }^{[37]}$. It has been demonstrated by in vitro studies that autophagy and autophagy-associated cell death in PC3 prostate cancer cells can be induced by $\mathrm{ATO}^{[38]}$. Clinically, lowering of serum cholesterol is the first effect of statin treatment; even though the inhibition of prostate cancer cell growth could seem independent from the lowering of serum cholesterol, both can be mediated by effects on the mevalonate pathway. Recently, it has been discovered that ATO inhibited the synthesis of geranylgeranyl pyrophosphate (i.e. an intermediate in the HMG-CoA reductase pathway used by organisms in the biosynthesis of terpenes and terpenoid), played an important role in the induction of autophagy and suppressing prostate cancer cell growth ${ }^{[39]}$. Specifically, the authors found a stress-responsive miRNA, called miR-182, which mediates the activity of ATO in prostate cancer cells.

\section{A landscape of ADT in prostate cancer}

In patients with advanced prostate cancer, ADT remains the most effective standard treatment, inducing programmed cell death and inhibiting cell proliferation ${ }^{[40]}$. Unfortunately, after short term remissions, cancer cells may escape from this treatment, survive and develop androgen-independent growing capabilities by several mechanisms ${ }^{[41]}$. Surviving tumor cells shows a phenotype known as Castration-resistant prostate cancer (CRPC) and death usually occurs within 3 years in the majority of patients ${ }^{[42]}$. The principal androgens produced in the testes are testosterone and the more active metabolite dihydrotestosterone. Androgens work after binding and trans-activating androgen receptor (AR), which regulates gene expression by interacting with different co-regulators during prostate cancer progression. The down-regulation of the levels of androgens, or preventing their entrance into prostate cancer cells, can reduce the tumor growth. To date, there are many hormone therapy protocols to achieve this goal. ADT is now performed with surgical castration (bilateral orchiectomy) or with luteinizing hormone-releasing hormone (LHRH) agonist therapy. 
LHRH can improve a disease-free phase and a moderate survival (if it's combined with primary radiation), reducing circulating testosterone levels to so-called castrate levels $(<0.5 \mathrm{ng} / \mathrm{mL})$. Anti-androgen therapy is part of the common hormone therapy that is used with drugs which can stop the action of particular hormones. Presently, the anti-androgen therapy is always combined with orchiectomy or with LHRH agonists as a first-line hormone therapy, referred as combined androgen blockade (CAB). During the first days of treatment with LHRH analogues there could be an overload of testosterone: to counteract this event, specific LHRH's antagonists have been proposed ${ }^{[43]}$.

At the first symptoms of metastasis, in CRPC patients, the cytotoxic chemotherapy is usually initiated ${ }^{[44]}$. Although cancer cells still express ARs, at some point they no longer respond to ADT, and prostate cancer become recurrent ${ }^{[45]}$. It has been discovered that there are some $A R$ mutations often expressed in hormonerefractory prostate cancer and these mutations cause a deregulation of transcriptional activity. These events are in contrast with the purpose of targeted therapies designed specifically to inhibit the receptor functions ${ }^{[46]}$. Eventually, it has been studied that prostate cancer cells can resist to ADT, surviving and developing an androgen independence in different ways, such as stimulating growth factor pathways, activating stressdependent survival genes, increasing cytoprotective chaperone networks, and escaping from apoptosis processes $^{[47-49]}$.

The regulatory effects of androgens on prostate cancer cells are still debated; in particular, the effects of modulation of the autophagy process during androgen deprivation have been investigated ${ }^{[50]}$. Previously, it was observed that autophagy was induced if androgen-sensitive LNCaP cells were cultured in the absence of serum; otherwise, if dihydrotestosterone was introduced, the autophagic process was reduced. This suggests that specific androgenic hormones produce a down regulation of autophagy process ${ }^{[51]}$. In addition, two independent studies have shown that cell death increases if LNCaP cells undergo androgen deprivation, suggesting that autophagic might exert a protection role toward prostate cancer cells $^{[51,52]}$.

\section{THE DIFFERENT EFFECTS OF AUTOPHAGY MODULATION IN PRECLINICAL MODELS OF PROSTATE CANCER CELLS \\ The autophagy process}

Autophagy is a homeostatic process whereby cellular components are engulfed into vesicles known as autophagosomes, which then fuse with lysosomes and are consequently subjected to proteolytic degradation ${ }^{[53]}$.

In 1963 the Nobel Laurate, Christian de Duve, introduced the concept of autophagy ${ }^{[54]}$, now this definition has been assigned to several intracellular processes, including micro- and macro-autophagy, chaperonemediated autophagy, and all of them eventually converge towards a common degradation phase mediated by lysosomes ${ }^{[55,56]}$.

Macro-autophagy, generally referred to as autophagy, has been experimentally proven to be involved in the pathogenesis of different diseases including cancer ${ }^{[57]}$.

At a molecular level, the kinase mTOR is a critical regulator of autophagy induction, with activated mTOR (MAPK and Akt signaling) it suppresses autophagy, whereas a negative regulation of mTOR, p53 and AMP-activated protein kinase (AMPK) signaling, promotes it. Three related serine/threonine kinases, UNC-51-like kinase -1, -2, and -3 (i.e. ULK1, ULK2 and UKL3) act downstream of the mTOR complex. ULK1 and ULK2 form a large complex with the mammalian homolog of an autophagy related gene product (mAtg13) and the scaffold protein FIP200. Class III phosphoinositide 3 kinase (PI3K) complex, containing hVps34, Beclin-1, p150, and Atg14-like protein or ultraviolet irradiation resistance-associated gene product (UVRAG), is required for the induction of autophagy. Autophagosome formation in controlled by Atg genes proteins through Atg12-Atg5 and LC3-II complexes. Atg12 is conjugated to Atg5 in an ubiquitin-like 
reaction that requires Atg7 and Atg10. The Atg12-Atg5 complex then interacts non-covalently with Atg16 to form a larger complex. LC3/Atg8 is cleaved at its C-terminus by Atg4 protease to generate the cytosolic LC3-I. LC3-I is then conjugated to phosphatidylethanolamine following an ubiquitin like reaction that requires Atg7 and Atg3. Then, the lipidated form of LC3, known as LC3-II, is attached to the autophagosome membrane.

An extensive crosstalk and a dynamic balance exists between apoptosis and autophagy. Autophagy is a survival mechanism that typically is switched on during a nutrient deficiency; however, its excessive activation can lead to cell death, with morphological features different from apoptosis ones. Proteins typically placed at the cross roads of this processes are Beclin-1 and Bcl-2. In particular, Beclin-1-dependent autophagy is inhibited by Bcl-2, which works as an anti-autophagic regulator and as a pro-survival mechanism ${ }^{[58]}$. Autophagy, like other metabolic pathways, can be regulated by various inducers and inhibitors. For example, autophagy can be induced by deprivation of amino acids or serum, whereas it can be reduced by 3-methyladenine (3-MA), an inhibitor of class III PI3K, that blocks the generation of phosphatidylinositol 3-phosphate (РI3P), an essential docking molecule for the formation of phagophores at early stage of autophagy. In addition, to investigate the autophagic flux some antibiotics are used such as bafilomycin A1 and concanamycin A, because they inhibit specific ATPase activities and acidification of the lysosome, and therefore the final fusion event between the lysosomes and autophagic vesicles ${ }^{[58]}$.

The process of autophagy has been identified as an important mechanism of cellular resistance, or alternatively of cell death ${ }^{[59,60]}$. Autophagy is a response to the cell's energy demand, whereby the loose cytoplasm and the cellular organelles undergo lysosomal degradation to compensate for the demand for alternative energy during periods of nutritional limitation. Besides the recycling of nutrients, autophagy also plays a role for degradating damaged organelles by proteolysis to maintain a cellular quality control.

A combined inhibition of autophagy and proteasome degradation pathway induces an accumulation of intracellular protein aggregates reminiscent of neuronal inclusion bodies, causing a significant cancer cell death than blocking the proteasome degradation pathway alone. As a result, proteasome inhibition activates autophagy via a eukaryotic initiation 2 alpha-dependent mechanism to eliminate protein aggregates and alleviate proteotoxic stress ${ }^{[6]}$. On the other hand, sustained autophagy under conditions of protracted starvation has also been proposed to lead to cell death; thus, the survival or death consequences of autophagy are condition-dependent ${ }^{[62-65]}$. Therefore, in cancer, autophagy has a controversial role, it can protect cancer cells from adverse conditions or induce the death of cancer cells. In particular, in human prostate cancer, autophagy is often impaired due to allelic loss of Beclin-1 locus ${ }^{[66]}$ or to the activation of the PI3K kinase/ Akt/mTOR pathway that finally inhibits autophagy. It has been demonstrated, in particular in in vitro studies on epithelial prostate cancer cells, that autophagy can provide a survival mechanism for cells that are undergoing some kind of starvation, favoring tumor growth ${ }^{[67]}$.

\section{Autophagy in prostate cancer}

As molecular events, cancer development is often associated with deletion or silencing of tumor suppressors genes such as PTEN, a negative regulator of the PI3K/Akt/mTOR pathway ${ }^{[68]}$, leading to resistance to various therapies in both preclinical and clinical trials ${ }^{[69]}$. Therefore, the PI3K/Akt/mTOR pathway plays a central role in various cellular processes, including protein cell survival, motility, synthesis, cell cycle, cell growth, and angiogenesis. The deregulation on this pathway may contribute to the malignant phenotype. Many small-molecule inhibitors targeting Akt, mTOR, and/or PI3K, and typically promotes growth arrest rather than cell death in solid tumors, and, therefore, use of small molecule inhibitors have been limited ${ }^{[70]}$. However, some of them have been successfully used in prostate cancer therapeutic schemes. In particular, some prostate cancer cell lines such as PC346-Flu1 and LNCaP were sensitive to monotherapy with the novel AKT inhibitor AZD5363, resulting in an increase in apoptosis at concentrations achievable in preclinical 
models ${ }^{[71]}$; on the contrary, other prostate cancer cell lines, such as PC3 and DU-145, were quite resistant to the treatment. Recently, Lamoureux et al. ${ }^{[72]}$ showed that AZD5363 induced cell death in the drug-resistant prostate cell lines by means of a chloroquine-mediated autophagy inactivation.

Chloroquine is known as a drug for the treatment of rheumatoid arthritis and malaria and to achieve an anti-HIV activity ${ }^{[73]}$. Chloroquine may be a clinically effective drug in prostate cancer, due to its ability to block lysosome acidification, preventing fusion with autophagosomes and, therefore, inhibiting the autophagy process ${ }^{[74]}$. Currently, many clinical trials used chloroquine to increase the effects of different targeted therapies such as bortezomib, temsirolimus, or gemcitabine in various cancers ${ }^{[75]}$. Early antitumor activities have been demonstrated in some of these trials. Furthermore, some studies evidenced that breast cancer cells could be sensitized to cisplatin by chloroquine, in an autophagy inhibition-independent manner, irrespective to Atg12 or Beclin-1 expression ${ }^{[76]}$. Previous studies reported that cell death in breast cancer ${ }^{[77]}$ and in glioma cells ${ }^{[78]}$ is increased by the combination of chloroquine (or other lysosomotropic agents) and PI3K pathway inhibitors. It was demonstrated that in vitro administration of D,L-sulforaphane (SFN), a synthetic racemic analogue of broccoli constituent L-sulforaphane, can inactivate histone deacetylase 6, therefore, interfering with the expression of androgen receptor genes in prostate cancer cells ${ }^{[79]}$. However, SNF also induced a cytoprotective autophagy in cultured human prostate cancer cells and it can be further enhanced with the pharmacologic inhibition of autophagy using chloroquine. The combined treatment was associated with decreased cell proliferation, increased apoptosis, alterations in protein levels of autophagy regulators Atg5 and phospho-mTOR, and suppression of biochemical features of epithelial-mesenchymal transition $^{[80]}$.

Pyruvate kinase isoenzyme type M2 (PKM2), a modulator of glycolysis, also regulates the autophagy process by up-regulating LC3B or Beclin-1 in glioma cells or in cancer-associated fibroblasts ${ }^{[1,82]}$. Since Sp-1 directly regulates PKM2, Ling et al. ${ }^{[15]}$ (2017) have recently found that a specific microRNA, miR-361-5p, inhibits CRPC cell proliferation, metabolism, and autophagy by directly targeting Sp1/PKM2 signaling, which is a potential target in PCa therapy.

Recently, it has been reported that the retinoic acid receptor responder (RARRES1)/tazarotene-induced gene-1 (TIG-1), a novel retinoid inducible gene first identified in skin raft cultures, modulates a series of signaling pathways inducing autophagy and inhibiting angiogenesis. The over-expression of RARRES1 can lead to the block of MAPK, to the increase of Beclin-1, Atg3, LC3-II protein expression, and finally, the inhibition of mTOR expression ${ }^{[83]}$. These studies strongly indicated the attractive prospect of blocking autophagy processes combined with targeted therapy as a promising therapeutic approach for prostate cancer ${ }^{[72]}$.

Zeng et al. ${ }^{[84]}$ (2018) have very recently investigated the role of a prostate leucine zipper protein (PrLZ) in combination with docetaxel-(the first-line standard approach in PCa) resistance in PCa, focusing on PrLZregulating autophagy pathway. PCa cells are protected from docetaxel induced-apoptosis by overexpression of PrLZ. The negative regulation of autophagy by PrLZ is mediated through LKB1/AMPK signaling pathway. The autophagy pathway and PrLZ can become a good therapeutic target for CRPC and, especially, docetaxelresistant CRPC therapy ${ }^{[8]}$. Autophagy has, generally, a protective function on cancer cells so maybe, if autophagy is properly inhibited, it could be a clinical strategy to contrast therapeutic resistance in prostate cancer, when is associated with partial failure of radiation or chemotherapeutic schemes ${ }^{[8]}$. On the contrary, in androgen-independent prostate cancer cells, it has been shown that autophagy induction may sensitize cells to radiation ${ }^{[86]}$. Despite these contrasting results, a therapeutic benefit for prostate cancer patients can come from either induction or inhibition of autophagy, depending on the specific tumor environment, and ultimately, to the adopted therapeutic scheme ${ }^{[49]}$. Radiation therapy is a cytoprotective autophagy inducer in prostate cancer cells ${ }^{[8]}$, it was also reported that incubation of LNCaP cells in serum-free medium lead to a pro-death autophagy process ${ }^{[67]}$. Li et al ${ }^{[51]}$ found out that the inhibition of autophagy can lead LNCaP 
cells to apoptosis in a serum-free medium, but not in cells in medium with serum or dihydrotestosterone. This suggest that autophagy process during androgen deprivation can protect LNCap cells from death. In other cancer cell lines it has been demonstrated that autophagy is modulated by growth factors contained in serum through activating the mTOR pathway ${ }^{[75]}$.

Cell death, in certain androgen deprivation situations under in vitro condition on epithelial prostate cancer cells, can arise by blocking autophagy processes via interfering with genetic or pharmacology means.

Furthermore, it has been observed that there is a parallelism between autophagy stimulation by androgenablation in prostate cancer cells and autophagy induction in some breast cancer cells during anti-hormone therapy. It was hypothesized that breast cancer cells tend to increase autophagy levels to develop a resistance to anti-estrogens ${ }^{[88]}$. To this regard, chloroquine induce cell death in LNCaP cells in a time and dose-dependent way, combined with an androgen deprivation ${ }^{[89]}$. At the same time, efficacy of androgen-ablation cell death can be enhanced by a combination of pharmacological inhibition of autophagy and chemotherapy ${ }^{\left[{ }^{[0]}\right]}$. Additional drugs that potentially are known to interfere with autophagy flux include bafilomycin A1, 3-methyladenine and pepstatin $\mathrm{A}^{[91]}$. However, these pharmacological molecules produces many off-target effects in different cellular pathways ${ }^{[91]}$.

At this moment there are not enough in vivo studies on the combination of androgen deprivation and autophagy inhibition, but the in vitro results obtained to date show the potentiality of the combination of conventional ADT and autophagy-modulation in prostate cancer patients ${ }^{[50]}$.

\section{Autophagy and androgen receptor interplay}

In regulation of prostate development as well as in carcinogenesis, AR is a critical transcription factor, but in the autophagy process, the role of AR remains poorly understood ${ }^{[92]}$. In fact, in PC3 AR-negative cells, statin is an autophagy inducer, but not in LNCaP AR-positive cells ${ }^{[93]}$. In contrast, in LNCaP cells autophagy process is inhibited by dihydrotestosterone treatment, but this does not happen in PC $3 \mathrm{cells}^{[51]}$. In addition, other studies showed that cell death may increase, under androgen deprivation by inhibiting autophagy process in LNCaP cells and suggesting a role of autophagy as a protector of prostate cancer cells ${ }^{[93,94]}$. Due to these contrasting results, in prostate cancer cell, the role of androgen/AR signals in altering autophagy remains unclear ${ }^{[95]}$. Traditional androgen deprivation therapy to treat prostate cancer may not reverse the AR regulated autophagy pathway because this pathway was found under different conditions at different androgen concentrations. In particular, Jiang et al. ${ }^{[95]}$ have used the compound ASC-J9 to specifically degrade AR in AR-positive cells.

Results revealed increased autophagy and decreased cell growth compared to those of sham-treated ARpositive cells. Therefore, targeting AR to promote autophagy may represent a new potential therapeutic approach to prostate cancer ${ }^{[39]}$.

It is emerging that different mechanisms regulate the autophagy process in androgen-ablation conditions ${ }^{[96]}$. In case of hypoxic conditions, autophagy can be induced by different independent pathways including the inhibition of mTOR kinase and hypoxia-inducible factors (HIF-1). Another mechanism that activate an autophagic response is controlled by energetic stress ${ }^{[94]}$. In particular, androgen deprivation may cause the genesis of autophagic vesicles which incorporate LD. The catabolism of lipids, known as lipophagy, represents a way to support energy demand and helps in the surviving of cells during $\mathrm{ADT}^{[25]}$. The loss of energy production leads to an activation of AMPK which, again, leads to suppression of mTOR signaling; this events cause fatty acid oxidation, glycolysis ${ }^{[97]}$ and, lastly, autophagy ${ }^{[98]}$. It is very interesting that about $40 \%$ human prostate cancers have an over-expression of AMPK, which confirms its activation in different metabolic pathways ${ }^{[99]}$. 
A recent work by Scherz-Shouval et al. ${ }^{[100]}$ showed that elevated levels of reacting oxygen species (ROS) activate autophagy. In addition, it was highlighted that androgen-mediated ROS generation promoted prostate cancer cell growth ${ }^{[101]}$, which provided the rationale that androgenic regulation of autophagy required a specific ROS signal. This evidence was recently further confirmed, reporting that elevated ROS levels contributed to the androgen-induced autophagy, to intracellular lipid accumulation, and finally to tumor cell growth ${ }^{[36]}$. Overall, it is clear that the regulation of ROS levels within the cells is critical: although too much ROS can trigger apoptosis, moderate levels promote cell signaling activities that are needed for both proliferation and survival ${ }^{[102]}$.

\section{Autophagy and apoptosis crosstalk in prostate cancer}

It is known that autophagy is particularly important as a survival mechanism in tumors with defects in the apoptotic pathway, supporting an already suggested therapeutic paradigm of a dual apoptotic and autophagic inhibition ${ }^{[103]}$. Prostate cancer cells could be sensitized to different apoptotic stimuli by inhibiting autophagy, which happens during ADT. In fact, appropriate stimuli can lead prostate cancer cells to apoptosis, even though these cells tend to evolve into an androgen-resistant phenotype ${ }^{[104]}$. To this regard, a recent investigation by Saleem et al. ${ }^{[105]}$ demonstrated that employing the well-established Bcl-2 inhibitor, ABT-737, in combination with chloroquine resulted in enhanced cytotoxicity in prostate cancer in vitro and in vivo. These results also highlighted the importance in clinical studies for the evaluation of the crosstalk pathways between apoptosis and autophagy ${ }^{[100]}$. Tumor necrosis factor-alpha (TNF- $\alpha$ ) and TNF-related apoptosisinducing ligand (TRAIL), members of the death receptor ligand superfamily, as apoptotic markers, have been suggested as potential anti-prostate cancer pharmacological targets ${ }^{[106,107]}$. In the LNCap cells the apoptotic response was enhanced by inhibiting pharmacological autophagy. Furthermore, the apoptotic cytotoxicity induced by TRAIL, in prostate cancer cell lines, was effectively increased by blocking autophagy by siRNAs targeting autophagic genes such as BECN1 or $A T G 7^{[108]}$.

Shin et al ${ }^{[109]}$ reported that docosahexaenoic acid (DHA), an omega-3 fatty acid present in cold-water fatty fishes, leads to mitochondrial ROS generation and reduces phospho-mTOR and phospho-Akt expression levels in concentration-dependent manner in p53-mutant DU145 and PC3 cells. These results suggest that DHA may be beneficial for patients with p53-mutant prostate cancer and show its possible use in clinical therapies ${ }^{[109]}$.

Many natural compounds are studied for their antitumor features. Recently, the effects of Marchantin M (Mar), a naturally occurring macrocyclicbisbibenzyls, have been tested, which resulted in a favorable apoptosis modulation ${ }^{[110]}$. Through this observation, it was hypothesized that caspase-independent mechanisms can also contribute to its cytotoxic effect on prostate cancer cells. Very recently, Jiang et al. ${ }^{[11]}$ revealed that the Mar-induced cell death was additionally associated with the activation of autophagy, together with the induction of ER stress and the inhibition of proteasome activity. These results enforced the goal of the identification of chemotherapeutic compounds able to trigger apoptotic as well as autophagic cell death in prostate cancer cells, for a successful application in cancer therapy.

\section{Novel molecular actors for autophagy tuning in prostate cancer models}

Recent contributions highlighted tyrosine kinases (TKs) and histone deacetylase (HDAC) inhibitors as promising modulators of autophagy activity in novel therapeutic schemes in prostate cancer models $\mathrm{s}^{[112]}$. It was reported that TKs play a key role in tumor sensitivity to radiation and chemical-induced apoptosis ${ }^{[113]}$. Nonreceptor tyrosine kinases (NRTK) are shown to participate in processes such as cell proliferation and migration in prostate cancer. There are several NRTK families, classified based on their structural similarities, that might potentially interfere with cell death balance in prostate cancer ${ }^{[23-25]}$. In particular, it has been shown that the administration of autophagy interfering molecules or drugs sensitized these cells toward Src tyrosine kinase inhibitor-based therapies ${ }^{[114]}$. Specifically, AR is phosphorylated by Src kinase complex, resulting in AR nuclear 
translocation and activation; it was additionally reported that this kinase played an important role in the development of castration-resistant disease state ${ }^{[115]}$. Indeed, tyrosine kinase inhibitors targeting Src can inhibit androgen-independent growth of prostate cancer cells, but did not induce significant apoptosis. Therefore, an autophagy blocking strategy might significantly potentiate the effects of tyrosine kinase inhibitors as proapoptotic inducers ${ }^{[116]}$. In addition to cell migration, Src assists in tumor invasion through its regulation of matrix metalloproteinases (MMPs) via degradation of the extracellular matrix. Another interaction that involves Src in $\mathrm{CaP}$ is with steroid receptors. It has been demonstrated that in low androgen conditions, AR can activate Scr in the cytoplasm, thereby triggering downstream signaling events independent of AR transcriptional and DNA-binding activity ${ }^{[38,48]}$. In fact, DNA synthesis can be inhibited by Src (as a dominant negative factor) after stimulation with low amount of androgens, but the Scr pathway can be bypassed with higher concentrations of androgen coupled with AR over-expression. Scr in addition to binding with AR, if stimulated with estradiol, can also interact with the estrogen receptor (ER) and thereby promote cell proliferation ${ }^{[38,49,50]}$ : thus, it can be hypothesized that Src serves as a scaffolding protein for the AR-ER complex.

Focal kinase (FAK) adhesion, in addition to migration and proliferation, may also be involved in angiogenesis and apoptosis in CaP cells. There are evidence that FAK induces vascular endothelial growth factor $(V E G F)$ transcription in an ERK1/2-dependent, Rap1-dependent, and Raf-dependent but Ras-independent manner ${ }^{[91-93]}$.

PTEN, a tumor suppressor gene with dual phosphatase activity, is part of the negative FAK regulators, and is deleted in the aggressive $\mathrm{CaP}^{[94]}$. The formation of the Lyn-PI3K-NEP complex can be regulated indirectly, in a negative way, by FAK ${ }^{[60]}$. ETK/BMX complex, discovered in 1994, belongs to the Tec family of NRTK ${ }^{[117]}$. In $\mathrm{CaP}$, ETK is downstream of PI3K on the induction of the neuroendocrine differentiation following IL-6 stimulation in LNCaP cells ${ }^{[118]}$. It is also know that it works as an anti-apoptotic factor. Ove-expression of ETK leads to a resistance to apoptosis in CaP cells due to its interaction with PI3K ${ }^{[118]}$. The activation of EKT do not require $\mathrm{PI} 3 \mathrm{~K}^{[27]}$. Rather, the interaction of ETK with p53 could be another mechanism of protection against apoptosis ${ }^{[119]}$. The introduction of ETK C-terminal fragment into PC-3 cells lead to apoptosis after proteolytic cleavage of ETK by caspases ${ }^{[120]}$. ETK is a signal transducer between SRC and AR downstream and FAK upstream. However, ETK alone is not enough efficient to activate AR, since it requires to interacts with Pim1 protein ${ }^{[117,121]}$.

Several studies have suggested that inhibition of HDAC in the progression of autophagy could be a new way for treatments of prostate cancer ${ }^{[122]}$. It is known that HDAC inhibitors are among the most promising targeted anticancer agents and are potent inducers of growth arrest, differentiation, and autophagic cell death of prostate cells ${ }^{[123]}$. Very recently, Patra et al. ${ }^{[124]}$ developed a novel HDAC inhibitor (MHY219) that induced cancer cell death and might be employed as a chemotherapy adjuvant in clinical studies. Similarly, other HDAC inhibitors have been tested in prostate cancer studies ${ }^{[125-127]}$. In another recent contribution, Vallo et al.$^{[122]}$ assayed PXD101, a potent pan HDAC inhibitor, to prevent the onset of castration-resistant phenotype and to potentiate hormonal therapy. A very interesting aspect is that there is a functional link between HDAC and liver X receptors (LXRs) members of the nuclear receptor family that regulates intracellular lipid homeostasis ${ }^{[128]}$. As already mentioned, lipids play a complex role in the progression and maintenance of prostate cancer. In fact, the increasing de novo synthesis of cholesterol and/or fatty acids is associated with the development of prostate cancer. Therefore, by inhibiting HDAC it was possible to reduce the levels of intracellular cholesterol and consequently it reduced the proliferation of tumor cells. Inhibitors HDCA and LXRs can, therefore, inhibit the proliferation of tumor cells ${ }^{[128]}$.

Currently, the only drug, approved to be applied in the chemotherapy of PCa, is docetaxel. Recently, a new drug was introduced, Salen-MN, a novel type of synthetic reagent bionic and exerts remarkable anticancer activities, but its effect is not been completely elucidated in PCa. In particular, treatment with Salen-Mn inhibited growth in PC-3 and DU145 cells. Moreover, Salen-Mn in vitro administration induced 
an increase in the expression of apoptotic proteins such as Bcl-2-associated X protein (Bax), cleaved poly (ADP-ribose) polymerase (PARP), and cleaved caspase-3. Furthermore, it has been observed that Salen-Mn induced expression of LC3-I/II in both dose- and time-dependent manner. It was documented that SalenMn increased autophagy by means of AMPK phosphorylation. Therefore, Salen-Mn might represent a novel promising candidate for the treatment of prostate cancer ${ }^{[129]}$.

\section{CONCLUDING REMARKS}

Basal autophagy helps to maintain homeostasis by contributing to organelle and protein turnover, but it is also a survival mechanism that is efficiently induced in stressed cells. Autophagy defects have been implicated in various health states and diseases, including infection, myopathy, Crohn's disease, neurodegeneration and cancer. However, the role of autophagy in cancer is quite complicated and still somewhat controversial; it appears to be tumor suppressive during cancer development, but contributes to tumor cell survival during cancer progression. Furthermore, tumor cells can use autophagy to resist to various anticancer therapies. Cancer cells experience higher metabolic and energy demands and exposed to stresses than normal cells because of their rapid proliferation and altered glycolytic metabolism. These cells depend more heavily on autophagy for survival.

The therapeutic benefits of various cancer therapies have been improved because of the inhibition of autophagy, which allows a methodology to specifically target cells characterized by higher levels of autophagy. There is still much to be discovered about autophagy and its regulation, but the ongoing results are delineating a promising pharmacological target for cancer treatment. However, it is necessary to discover additional biomarkers to evaluate the complex dynamism of autophagy processes and to establish new methods to assess autophagy in clinical samples.

The data here reviewed from the current scientific literature generally indicated that the modulation of autophagy may be therapeutically beneficial in various tumors because of their ability to sensitize cancer cells to the different therapies, including DNA-damaging agents, anti-hormone therapies and radiation and chemotherapeutic combined strategies.

In particular, it is emerging that in prostate cancer, a promising combined treatment during androgen deprivation therapy is to target metabolic stress-induced signaling pathways. These complex pathways are intimately controlled by various molecular actors that play important roles in programmed cell death pathways including autophagy and apoptosis. In particular, autophagy is clearly becoming a central regulator of the main physiological and pathological processes, which through a precise and sensitive balancing determine pro-death or pro-survival fate of the cell. Therefore, the modulation of autophagy process in malignant cell types can be regarded as a potential strategy in cancer therapy.

\section{DECLARATIONS}

\section{Authors' contributions}

Manuscript writing: Gabriele F, Martinelli C

Supervised the final version: Comincini S

\section{Financial support and sponsorship}

None.

\section{Conflicts of interest}

The authors declare that there is no conflict of interests regarding the publication of this paper. 


\section{Patient consent}

Not applicable.

\section{Ethics approval}

Not applicable.

\section{Copyright}

(C) The Author(s) 2018.

\section{REFERENCES}

1. Siegel R, Ward E, Brawley O, Jemal A. Cancer statistics, 2011: the impact of eliminating socioeconomic and racial disparities on premature cancer deaths. CA Cancer J Clin 2011;61:212-36.

2. Baade PD, Youlden DR, Krnjacki LJ. International epidemiology of prostate cancer: geographical distribution and secular trends. Mol Nutr Food Res 2009;53:171-84.

3. Aus G, Abbou CC, Bolla M, Heidenreich A, Schmid HP, van Poppel H, Wolff J, Zattoni F; European Association of Urology. EAU Guidelines on prostate cancer. Eur Urol 2005;48:546-51.

4. Borley N, Feneley MR. Prostate cancer: diagnosis and staging. Asian J Androl 2009;11:74-80.

5. Steinberg GD, Carter BS, Beaty TH, Childs B, Walsh PC. Family history and the risk of prostate cancer. Prostate 1990;17:337-47.

6. Lichtenstein P, Holm NV, Verkasalo PK, Iliadou A, Kaprio J, Koskenvuo M, Pukkala E, Skytthe A, Hemminki K. Environmental and heritable factors in the causation of cancer-analyses of cohorts of twins from Sweden, Denmark, and Finland. $N$ Engl $J$ Med 2000;343:78-85.

7. Struewing JP, Hartge P, Wacholder S, Baker SM, Berlin M, McAdams M, Timmerman MM, Brody LC, Tucker MA. The risk of cancer associated with specific mutations of BRCA1 and BRCA2 among Ashkenazi Jews. N Engl J Med 1997;336:1401-8.

8. Gallagher RP, Fleshner N. Prostate cancer: 3. Individual risk factors. CMAJ 1998;159:807-13.

9. Eeles RA, Kote-Jarai Z, Giles GG, Olama AA, Guy M, Jugurnauth SK, Mulholland S, Leongamornlert DA, Edwards SM, Morrison J, Field HI, Southey MC, Severi G, Donovan JL, Hamdy FC, Dearnaley DP, Muir KR, Smith C, Bagnato M, Ardern-Jones AT, Hall AL, O’Brien LT, Gehr-Swain BN, Wilkinson RA, Cox A, Lewis S, Brown PM, Jhavar SG, Tymrakiewicz M, Lophatananon A, Bryant SL; UK Genetic Prostate Cancer Study Collaborators; British Association of Urological Surgeons' Section of Oncology; UK ProtecT Study Collaborators; Horwich A, Huddart RA, Khoo VS, Parker CC, Woodhouse CJ, Thompson A, Christmas T, Ogden C, Fisher C, Jamieson C, Cooper CS, English DR, Hopper JL, Neal DE, Easton DF. Multiple newly identified loci associated with prostate cancer susceptibility. Nat Genet 2008;40:316-21.

10. Li Q, Gu C, Zhu Y, Wang M, Yang Y, Wang J, Jin L, Zhu ML, Shi TY, He J, Zhou X, Ye DW, Wei Q. Polymorphisms in the mTOR gene and risk of sporadic prostate cancer in an Eastern Chinese population. PLoS One 2013;8:e71968.

11. Chuang AY, DeMarzo AM, Veltri RW, Sharma RB, Bieberich CJ, Epstein JI. Immunohistochemical differentiation of high-grade prostate carcinoma from urothelial carcinoma. Am J Surg Pathol 2007;31:1246-55.

12. Catz SD, Johnson JL. BCL-2 in prostate cancer: a minireview. Apoptosis 2003;8:29-37.

13. Chakravarthi S, Yang DLW, Thanikachalam P, Nagaraja HS, Bukhari NI. Assessment of proliferative index and its association with Ki67 antigen molecule expression in nodular hyperplasia of prostate. Indian J Sci Technol 2009;2:1-4.

14. Ramsay AK, McCracken SR, Soofi M, Fleming J, Yu AX, Ahmad I, Morland R, Machesky L, Nixon C, Edwards DR, Nuttall RK, Seywright M, Marquez R, Keller E, Leung HY. ERK5 signalling in prostate cancer promotes an invasive phenotype. Br J Cancer 2011;104:664-72.

15. Ling Z, Liu D, Zhang G, Liang Q, Xiang P, Xu Y, Han C, Tao T. miR-361-5p modulates metabolism and autophagy via the Sp1mediated regulation of PKM2 in prostate cancer. Onco Rep 2017;38:1621-8.

16. Wang R, Xu J, Saramäki O, Visakorpi T, Sutherland WM, Zhou J, Sen B, Lim SD, Mabjeesh N, Amin M, Dong JT, Petros JA, Nelson PS, Marshall FF, Zhau HE, Chung LW. PrLZ, a novel prostate-specific and androgen-responsive gene of the TPD52 family, amplified in chromosome 8q21.1 and overexpressed in human prostate cancer. Cancer Res 2004;64:1589-94.

17. Garber K. Energy deregulation: licensing tumors to grow. Science 2006;312:1158-9.

18. Liu Y. Fatty acid oxidation is a dominant bioenergetic pathway in prostate cancer. Prostate Cancer Prostatic Dis 2006;9:230-4 .

19. Warburg O. On the origin of cancer cells. Science 1956;123:309-14.

20. Horoszewicz JS, Leong SS, Kawinski E, Karr JP, Rosenthal H, Chu TM, Mirand EA, Murphy GP. LNCaP model of human prostatic carcinoma. Cancer Res 1983;43:1809-18.

21. Singh G, Lakkis CL, Laucirica R, Epner DE. Regulation of prostate cancer cell division by glucose. J Cell Physiol 1999;180:431-8.

22. Kaini RR, Sillerud LO, Zhaorigetu S, Hu CA. Autophagy regulates lipopysis and cell survival though lipid droplet degradation in androgen-sensitive prostate cance cells. Prostate 2012;72:1412-22.

23. DiPaola RS, Dvorzhinski D, Thalasila A, Garikapaty V, Doram D, May M, Bray K, Mathew R, Beaudoin B, Karp C, Stein M, Foran DJ, White E. Therapeutic starvation and autophagy in prostate cancer: a new paradigm for targeting metabolism in cancer therapy. Prostate 2008;68:1743-52. 
24. Swinnen JV, Brusselmans K, Verhoeven G. Increased lipogenesis in cancer cells: new players, novel targets. Curr Opin Clin Nutr Metab Care 2006;9:358-65.

25. Migita T, Ruiz S, Fornari A, Fiorentino M, Priolo C, Zadra G, Inazuka F, Grisanzio C, Palescandolo E, Shin E, Fiore C, Xie W, Kung AL, Febbo PG, Subramanian A, Mucci L, Ma J, Signoretti S, Stampfer M, Hahn WC, Finn S, Loda M. Fatty acid synthase: a metabolic enzyme and candidate oncogene in prostate cancer. J Natl Cancer Inst 2009;101:519-32.

26. Flavin R, Zadra G, Loda M. Metabolic alterations and targeted therapies in prostate cancer. J Pathol 2011;223:283-94.

27. Hatzivassiliou G, Zhao F, Bauer DE, Andreadis C, Shaw AN, Dhanak D, Hingorani SR, Tuveson DA, Thompson CB. ATP citrate lyase inhibition can suppress tumor cell growth. Cancer Cell 2005;8:311-21.

28. Beckers A, Organe S, Timmermans L, Scheys K, Peeters A, Brusselmans K, Verhoeven G, Swinnen JV. Chemical inhibition of acetylCoA carboxylase induces growth arrest and cytotoxicity selectively in cancer cells. Cancer Res 2007;67:8180-7.

29. Swinnen JV, Esquenet M, Goossens K, Heyns W, Verhoeven G. Androgens stimulate fatty acid synthase in the human prostate cancer cell line LNCaP. Cancer Res 1997;57:1086-90.

30. Farese RV Jr, Walther TC. Lipid droplets finally get a little R-E-S-P-E-C-T. Cell 2009;139:855-60.

31. Brasaemle DL. Thematic review series: adipocyte biology. The perilipin family of structural lipid droplet proteins: stabilization of lipid droplets and control of lipolysis. J Lipid Res 2007;48:2547-59.

32. Singh R, Kaushik S, Wang Y, Xiang Y, Novak I, Komatsu M, Tanaka K, Cuervo AM, Czaja MJ. Autophagy regulates lipid metabolism. Nature 2009;458:1131-5.

33. Rodriguez-Navarro JA, Cuervo AM. Autophagy and lipids: tightening the knot. Semin Immunopathol 2010;32:343-53.

34. Fritz V, Benfodda Z, Rodier G, Henriquet C, Iborra F. Abrogation of de novo lipogenesis by stearoyl-CoA desaturase 1 inhibition interferes with oncogenic signaling and blocks prostate cancer progression in mice. Mol Cancer Ther 2010;9:1740-54.

35. Rysman E, Brusselmans K, Scheys K, Timmermans L, Derua R. De novo lipogenesis protects cancer cells from free radicals and chemotherapeutics by promoting membrane lipid saturation. Cancer Res 2010;70:8117-26.

36. Shi Y, Han JJ, Tennakoon JB, Mehta FF, Merchant FA, Burns AR, Howe MK, McDonnell DP, Frigo DE. Androgens promote prostate cancer cell growth through induction of autophagy. Mol Endocrinol 2013;27:280-95.

37. Zheng X, Cui XX, Gao Z, Zhao Y, Shi Y, Huang MT, Liu Y, Wagner GC, Lin Y, Shih WJ, Rao CV, Yang CS, Conney AH. Inhibitory effect of dietary atorvastatin and celecoxib together with voluntary running wheel exercise on the progression of androgen-dependent LNCaP prostate tumors to androgen independence. Exp Ther Med 2011;2:221-8.

38. Toepfer N, Childress C, Parikh A, Rukstalis D, Yang W. Atorvastatin induces autophagy in prostate cancer PC3 cells through activation of LC3 transcription. Cancer Biol Thervol 2011;12:691-9.

39. Peng X, Li W, Yuan L, Mehta RG, Kopelovich L, McCormick DL. Inhibition of proliferation and induction of autophagy by atorvastatin in PC3 prostate cancer cells correlate with downregulation of Bc12 and upregulation of miR-182 and p21. PLoS One 2013;8:e70442.

40. Kyprianou N, English HF, Isaacs JT. Programmed cell death during regression of PC-82 human prostate cancer following androgen ablation. Cancer Res 1990;50:3748-53.

41. Dutt SS, Gao AC. Molecular mechanisms of castration-resistant prostate cancer progression. Future Oncol 2009;5:1403-13.

42. Gleave ME, Bruchovsky N, Moore MJ, Venner P. Prostate cancer: 9. Treatment of advanced disease. CMAJ 1999;160:225-32.

43. Boccon-Gibod L, van der Meulen E, Persson BE. An update on the use of gonadotropin-hormone antagonists in prostate cancer. Ther Adv Urol 2011;3:127-40.

44. Oudard S. Progress in emerging therapies for advanced prostate cancer. Cancer Treat Rev 2013;39:275-89.

45. Mostaghel EA, Page ST, Lin DW, Fazli L, Coleman IM, True LD, Knudsen B, Hess DL, Nelson CC, Matsumoto AM, Bremner WJ, Gleave ME, Nelson PS. Intraprostatic androgens and androgen-regulated gene expression persist after testosterone suppression: therapeutic implications for castration-resistant prostate cancer. Cancer Res 2007;67:5033-41.

46. Saraon P, Jarvi K, Diamandis EP. Molecular alterations during progression of prostate cancer to androgen independence. Clin Chem 2011;57:1366-75.

47. Knudsen KE, Scher HI. Starving the addiction: new opportunities for durable suppression of AR signaling in prostate cancer. Clin Cancer Res 2009;15:4792-8.

48. Miyake H, Nelson C, Rennie PS, Gleave ME. Overexpression of insulin-like growth factor binding protein-5 helps accelerate progression to androgen-independence in the human prostate $\mathrm{LNCaP}$ tumor model through activation of phosphatidylinositol 3'-kinase pathway. Endocrinology 2000;141:2257-65.

49. Rocchi P, So A, Kojima S, Signaevsky M, Beraldi E, Fazli L, Hurtado-Coll A, Yamanaka K, Gleave M. Heat shock protein 27 increases after androgen ablation and plays a cytoprotective role in hormone-refractory prostate cancer. Cancer Res 2004;64:6595-602.

50. Ziparo E, Petrungaro S, Marini ES, Starace D, Conti S, Facchiano A, Filippini A, Giampietri C. Autophagy in prostate cancer and androgensuppressiontherapy. Int J Mol Sci 2013;14:12090-106.

51. Li M, Jiang X, Liu D, Na Y, Gao GF, Xi Z. Autophagy protects LNCaP cells under androgen deprivation conditions. Autophagy 2008;4:54-60.

52. Bennett HL, Fleming JT, O'Prey J, Ryan KM, Leung HY. Androgens modulate autophagy and cell death via regulation of the endoplasmic reticulum chaperone glucose-regulated protein 78/BiP in prostate cancer cells. Cell Death Dis 2010;1:e72.

53. Mizushima N, Levine B, Cuervo AM, Klionsky DJ. Autophagy fights disease through cellular self-digestion. Nature 2008;45:1069-75.

54. Deter RL, Baudhuin P, De Duve C. Participation of lysosomes in cellular autophagy induced in rat liver by glucagon.. J Cell Biol 1967;35:C11-6.

55. Cuervo AM. Autophagy: many paths to the same end. Mol Cell Biochem 2004;263:55-72. 
56. Galluzzi L, Vicencio JM, Kepp O, Tasdemir E, Maiuri MC, Kroemer G. To die or not to die: that is the autophagic question. Curr Mol Med 2008;8:78-91.

57. Levine B, Kroemer G. Autophagy in the pathogenesis of disease. Cell 2008;132:27-42.

58. Klionsky DJ, Abdalla FC, Abeliovich H, Abraham RT, Acevedo-Arozena A, Adeli K, Agholme L, Agnello M, Agostinis P, AguirreGhiso JA, Ahn HJ, Ait-Mohamed O, Ait-Si-Ali S, Akematsu T, Akira S, Al-Younes HM, Al-Zeer MA, Albert ML, Albin RL, AlegreAbarrategui J, Aleo MF, Alirezaei M, Almasan A, Almonte-Becerril M, Amano A, Amaravadi R, Amarnath S, Amer AO, AndrieuAbadie N, Anantharam V, Ann DK, Anoopkumar-Dukie S, Aoki H, Apostolova N, Arancia G, Aris JP, Asanuma K, Asare NY, Ashida H, Askanas V, Askew DS, Auberger P, Baba M, Backues SK, Baehrecke EH, Bahr BA, Bai XY, Bailly Y, Baiocchi R, Baldini G, Balduini W, Ballabio A, Bamber BA, Bampton ET, Bánhegyi G, Bartholomew CR, Bassham DC, Bast RC Jr, Batoko H, Bay BH, Beau I, Béchet DM, Begley TJ, Behl C, Behrends C, Bekri S, Bellaire B, Bendall LJ, Benetti L, Berliocchi L, Bernardi H, Bernassola F, Besteiro S, Bhatia-Kissova I, Bi X, Biard-Piechaczyk M, Blum JS, Boise LH, Bonaldo P, Boone DL, Bornhauser BC, Bortoluci KR, Bossis I, Bost F, Bourquin JP, Boya P, Boyer-Guittaut M, Bozhkov PV, Brady NR, Brancolini C, Brech A, Brenman JE, Brennand A, Bresnick EH, Brest P, Bridges D, Bristol ML, Brookes PS, Brown EJ, Brumell JH, Brunetti-Pierri N, Brunk UT, Bulman DE, Bultman SJ, Bultynck G, Burbulla LF, Bursch W, Butchar JP, Buzgariu W, Bydlowski SP, Cadwell K, Cahová M, Cai D, Cai J, Cai Q, Calabretta B, CalvoGarrido J, Camougrand N, Campanella M, Campos-Salinas J, Candi E, Cao L, Caplan AB, Carding SR, Cardoso SM, Carew JS, Carlin CR, Carmignac V, Carneiro LA, Carra S, Caruso RA, Casari G, Casas C, Castino R, Cebollero E, Cecconi F, Celli J, Chaachouay H, Chae HJ, Chai CY, Chan DC, Chan EY, Chang RC, Che CM, Chen CC, Chen GC, Chen GQ, Chen M, Chen Q, Chen SS, Chen W, Chen X, Chen X, Chen X, Chen YG, Chen Y, Chen Y, Chen YJ, Chen Z, Cheng A, Cheng CH, Cheng Y, Cheong H, Cheong JH, Cherry S, Chess-Williams R, Cheung ZH, Chevet E, Chiang HL, Chiarelli R, Chiba T, Chin LS, Chiou SH, Chisari FV, Cho CH, Cho DH, Choi AM, Choi D, Choi KS, Choi ME, Chouaib S, Choubey D, Choubey V, Chu CT, Chuang TH, Chueh SH, Chun T, Chwae YJ, Chye ML, Ciarcia R, Ciriolo MR, Clague MJ, Clark RS, Clarke PG, Clarke R, Codogno P, Coller HA, Colombo MI, Comincini S, Condello M, Condorelli F, Cookson MR, Coombs GH, Coppens I, Corbalan R, Cossart P, Costelli P, Costes S, Coto-Montes A, Couve E, Coxon FP, Cregg JM, Crespo JL, Cronjé MJ, Cuervo AM, Cullen JJ, Czaja MJ, D’Amelio M, Darfeuille-Michaud A, Davids LM, Davies FE, De Felici M, de Groot JF, de Haan CA, De Martino L, De Milito A, De Tata V, Debnath J, Degterev A, Dehay B, Delbridge LM, Demarchi F, Deng YZ, Dengjel J, Dent P, Denton D, Deretic V, Desai SD, Devenish RJ, Di Gioacchino M, Di Paolo G, Di Pietro C, Díaz-Araya G, Díaz-Laviada I, Diaz-Meco MT, Diaz-Nido J, Dikic I, Dinesh-Kumar SP, Ding WX, Distelhorst CW, Diwan A, Djavaheri-Mergny M, Dokudovskaya S, Dong Z, Dorsey FC, Dosenko V, Dowling JJ, Doxsey S, Dreux M, Drew ME, Duan Q, Duchosal MA, Duff K, Dugail I, Durbeej M, Duszenko M, Edelstein CL, Edinger AL, Egea G, Eichinger L, Eissa NT, Ekmekcioglu S, El-Deiry WS, Elazar Z, Elgendy M, Ellerby LM, Eng KE, Engelbrecht AM, Engelender S, Erenpreisa J, Escalante R, Esclatine A, Eskelinen EL, Espert L, Espina V, Fan H, Fan J, Fan QW, Fan Z, Fang S, Fang Y, Fanto M, Fanzani A, Farkas T, Farré JC, Faure M, Fechheimer M, Feng CG, Feng J, Feng Q, Feng Y, Fésüs L, Feuer R, Figueiredo-Pereira ME, Fimia GM, Fingar DC, Finkbeiner S, Finkel T, Finley KD, Fiorito F, Fisher EA, Fisher PB, Flajolet M, Florez-McClure ML, Florio S, Fon EA, Fornai F, Fortunato F, Fotedar R, Fowler DH, Fox HS, Franco R, Frankel LB, Fransen M, Fuentes JM, Fueyo J, Fujii J, Fujisaki K, Fujita E, Fukuda M, Furukawa RH, Gaestel M, Gailly P, Gajewska M, Galliot B, Galy V, Ganesh S, Ganetzky B, Ganley IG, Gao FB, Gao GF, Gao J, Garcia L, Garcia-Manero G, Garcia-Marcos M, Garmyn M, Gartel AL, Gatti E, Gautel M, Gawriluk TR, Gegg ME, Geng J, Germain M, Gestwicki JE, Gewirtz DA, Ghavami S, Ghosh P, Giammarioli AM, Giatromanolaki AN, Gibson SB, Gilkerson RW, Ginger ML, Ginsberg HN, Golab J, Goligorsky MS, Golstein P, Gomez-Manzano C, Goncu E, Gongora C, Gonzalez CD, Gonzalez R, González-Estévez C, González-Polo RA, Gonzalez-Rey E, Gorbunov NV, Gorski S, Goruppi S, Gottlieb RA, Gozuacik D, Granato GE, Grant GD, Green KN, Gregorc A, Gros F, Grose C, Grunt TW, Gual P, Guan JL, Guan KL, Guichard SM, Gukovskaya AS, Gukovsky I, Gunst J, Gustafsson AB, Halayko AJ, Hale AN, Halonen SK, Hamasaki M, Han F, Han T, Hancock MK, Hansen M, Harada H, Harada M, Hardt SE, Harper JW, Harris AL, Harris J, Harris SD, Hashimoto M, Haspel JA, Hayashi S, Hazelhurst LA, He C, He YW, Hébert MJ, Heidenreich KA, Helfrich MH, Helgason GV, Henske EP, Herman B, Herman PK, Hetz C, Hilfiker S, Hill JA, Hocking LJ, Hofman P, Hofmann TG, Höhfeld J, Holyoake TL, Hong MH, Hood DA, Hotamisligil GS, Houwerzijl EJ, Høyer-Hansen M, Hu B, Hu CA, Hu HM, Hua Y, Huang C, Huang J, Huang S, Huang WP, Huber TB, Huh WK, Hung TH, Hupp TR, Hur GM, Hurley JB, Hussain SN, Hussey PJ, Hwang JJ, Hwang S, Ichihara A, Ilkhanizadeh S, Inoki K, Into T, Iovane V, Iovanna JL, Ip NY, Isaka Y, Ishida H, Isidoro C, Isobe K, Iwasaki A, Izquierdo M, Izumi Y, Jaakkola PM, Jäättelä M, Jackson GR, Jackson WT, Janji B, Jendrach M, Jeon JH, Jeung EB, Jiang H, Jiang H, Jiang JX, Jiang M, Jiang Q, Jiang X, Jiang X, Jiménez A, Jin M, Jin S, Joe CO, Johansen T, Johnson DE, Johnson GV, Jones NL, Joseph B, Joseph SK, Joubert AM, Juhász G, Juillerat-Jeanneret L, Jung CH, Jung YK, Kaarniranta K, Kaasik A, Kabuta T, Kadowaki M, Kagedal K, Kamada Y, Kaminskyy VO, Kampinga HH, Kanamori H, Kang C, Kang KB, Kang KI, Kang R, Kang YA, Kanki T, Kanneganti TD, Kanno H, Kanthasamy AG, Kanthasamy A, Karantza V, Kaushal GP, Kaushik S, Kawazoe Y, Ke PY, Kehrl JH, Kelekar A, Kerkhoff C, Kessel DH, Khalil H, Kiel JA, Kiger AA, Kihara A, Kim DR, Kim DH, Kim DH, Kim EK, Kim HR, Kim JS, Kim JH, Kim JC, Kim JK, Kim PK, Kim SW, Kim YS, Kim Y, Kimchi A, Kimmelman AC, King JS, Kinsella TJ, Kirkin V, Kirshenbaum LA, Kitamoto K, Kitazato K, Klein L, Klimecki WT, Klucken J, Knecht E, Ko BC, Koch JC, Koga H, Koh JY, Koh YH, Koike M, Komatsu M, Kominami E, Kong HJ, Kong WJ, Korolchuk VI, Kotake Y, Koukourakis MI, Kouri Flores JB, Kovács AL, Kraft C, Krainc D, Krämer H, Kretz-Remy C, Krichevsky AM, Kroemer G, Krüger R, Krut O, Ktistakis NT, Kuan CY, Kucharczyk R, Kumar A, Kumar R, Kumar S, Kundu M, Kung HJ, Kurz T, Kwon HJ, La Spada AR, Lafont F, Lamark T, Landry J, Lane JD, Lapaquette P, Laporte JF, László L, Lavandero S, Lavoie JN, Layfield R, Lazo PA, Le W, Le Cam L, Ledbetter DJ, Lee AJ, Lee BW, Lee GM, Lee J, Lee JH, Lee M, Lee MS, Lee SH, Leeuwenburgh C, Legembre P, Legouis R, Lehmann M, Lei HY, Lei QY, Leib DA, Leiro J, Lemasters JJ, Lemoine A, Lesniak MS, Lev D, Levenson VV, Levine B, Levy E, Li F, Li JL, Li L, Li S, Li W, Li XJ, Li YB, Li YP, Liang C, Liang Q, Liao YF, Liberski PP, Lieberman A, Lim HJ, Lim KL, Lim K, Lin CF, Lin FC, Lin J, Lin JD, Lin K, Lin WW, Lin WC, Lin YL, Linden R, Lingor P, Lippincott-Schwartz J, Lisanti 
MP, Liton PB, Liu B, Liu CF, Liu K, Liu L, Liu QA, Liu W, Liu YC, Liu Y, Lockshin RA, Lok CN, Lonial S, Loos B, Lopez-Berestein G, López-Otín C, Lossi L, Lotze MT, Lőw P, Lu B, Lu B, Lu B, Lu Z, Luciano F, Lukacs NW, Lund AH, Lynch-Day MA, Ma Y, Macian F, MacKeigan JP, Macleod KF, Madeo F, Maiuri L, Maiuri MC, Malagoli D, Malicdan MC, Malorni W, Man N, Mandelkow EM, Manon S, Manov I, Mao K, Mao X, Mao Z, Marambaud P, Marazziti D, Marcel YL, Marchbank K, Marchetti P, Marciniak SJ, Marcondes M, Mardi M, Marfe G, Mariño G, Markaki M, Marten MR, Martin SJ, Martinand-Mari C, Martinet W, Martinez-Vicente M, Masini M, Matarrese P, Matsuo S, Matteoni R, Mayer A, Mazure NM, McConkey DJ, McConnell MJ, McDermott C, McDonald C, McInerney GM, McKenna SL, McLaughlin B, McLean PJ, McMaster CR, McQuibban GA, Meijer AJ, Meisler MH, Meléndez A, Melia TJ, Melino G, Mena MA, Menendez JA, Menna-Barreto RF, Menon MB, Menzies FM, Mercer CA, Merighi A, Merry DE, Meschini S, Meyer CG, Meyer TF, Miao CY, Miao JY, Michels PA, Michiels C, Mijaljica D, Milojkovic A, Minucci S, Miracco C, Miranti CK, Mitroulis I, Miyazawa K, Mizushima N, Mograbi B, Mohseni S, Molero X, Mollereau B, Mollinedo F, Momoi T, Monastyrska I, Monick MM, Monteiro MJ, Moore MN, Mora R, Moreau K, Moreira PI, Moriyasu Y, Moscat J, Mostowy S, Mottram JC, Motyl T, Moussa CE, Müller S, Muller S, Münger K, Münz C, Murphy LO, Murphy ME, Musarò A, Mysorekar I, Nagata E, Nagata K, Nahimana A, Nair U, Nakagawa T, Nakahira K, Nakano H, Nakatogawa H, Nanjundan M, Naqvi NI, Narendra DP, Narita M, Navarro M, Nawrocki ST, Nazarko TY, Nemchenko A, Netea MG, Neufeld TP, Ney PA, Nezis IP, Nguyen HP, Nie D, Nishino I, Nislow C, Nixon RA, Noda T, Noegel AA, Nogalska A, Noguchi S, Notterpek L, Novak I, Nozaki T, Nukina N, Nürnberger T, Nyfeler B, Obara K, Oberley TD, Oddo S, Ogawa M, Ohashi T, Okamoto K, Oleinick NL, Oliver FJ, Olsen LJ, Olsson S, Opota O, Osborne TF, Ostrander GK, Otsu K, Ou JH, Ouimet M, Overholtzer M, Ozpolat B, Paganetti P, Pagnini U, Pallet N, Palmer GE, Palumbo C, Pan T, Panaretakis T, Pandey UB, Papackova Z, Papassideri I, Paris I, Park J, Park OK, Parys JB, Parzych KR, Patschan S, Patterson C, Pattingre S, Pawelek JM, Peng J, Perlmutter DH, Perrotta I, Perry G, Pervaiz S, Peter M, Peters GJ, Petersen M, Petrovski G, Phang JM, Piacentini M, Pierre P, Pierrefite-Carle V, Pierron G, Pinkas-Kramarski R, Piras A, Piri N, Platanias LC, Pöggeler S, Poirot M, Poletti A, Poüs C, Pozuelo-Rubio M, Prætorius-Ibba M, Prasad A, Prescott M, Priault M, Produit-Zengaffinen N, Progulske-Fox A, ProikasCezanne T, Przedborski S, Przyklenk K, Puertollano R, Puyal J, Qian SB, Qin L, Qin ZH, Quaggin SE, Raben N, Rabinowich H, Rabkin SW, Rahman I, Rami A, Ramm G, Randall G, Randow F, Rao VA, Rathmell JC, Ravikumar B, Ray SK, Reed BH, Reed JC, Reggiori F, Régnier-Vigouroux A, Reichert AS, Reiners JJ Jr, Reiter RJ, Ren J, Revuelta JL, Rhodes CJ, Ritis K, Rizzo E, Robbins J, Roberge M, Roca H, Roccheri MC, Rocchi S, Rodemann HP, Rodríguez de Córdoba S, Rohrer B, Roninson IB, Rosen K, Rost-Roszkowska MM, Rouis M, Rouschop KM, Rovetta F, Rubin BP, Rubinsztein DC, Ruckdeschel K, Rucker EB 3rd, Rudich A, Rudolf E, Ruiz-Opazo N, Russo R, Rusten TE, Ryan KM, Ryter SW, Sabatini DM, Sadoshima J, Saha T, Saitoh T, Sakagami H, Sakai Y, Salekdeh GH, Salomoni P, Salvaterra PM, Salvesen G, Salvioli R, Sanchez AM, Sánchez-Alcázar JA, Sánchez-Prieto R, Sandri M, Sankar U, Sansanwal P, Santambrogio L, Saran S, Sarkar S, Sarwal M, Sasakawa C, Sasnauskiene A, Sass M, Sato K, Sato M, Schapira AH, Scharl M, Schätzl HM, Scheper W, Schiaffino S, Schneider C, Schneider ME, Schneider-Stock R, Schoenlein PV, Schorderet DF, Schüller C, Schwartz GK, Scorrano L, Sealy L, Seglen PO, Segura-Aguilar J, Seiliez I, Seleverstov O, Sell C, Seo JB, Separovic D, Setaluri V, Setoguchi T, Settembre C, Shacka JJ, Shanmugam M, Shapiro IM, Shaulian E, Shaw RJ, Shelhamer JH, Shen HM, Shen WC, Sheng ZH, Shi Y, Shibuya K, Shidoji Y, Shieh JJ, Shih CM, Shimada Y, Shimizu S, Shintani T, Shirihai OS, Shore GC, Sibirny AA, Sidhu SB, Sikorska B, Silva-Zacarin EC, Simmons A, Simon AK, Simon HU, Simone C, Simonsen A, Sinclair DA, Singh R, Sinha D, Sinicrope FA, Sirko A, Siu PM, Sivridis E, Skop V, Skulachev VP, Slack RS, Smaili SS, Smith DR, Soengas MS, Soldati T, Song X, Sood AK, Soong TW, Sotgia F, Spector SA, Spies CD, Springer W, Srinivasula SM, Stefanis L, Steffan JS, Stendel R, Stenmark H, Stephanou A, Stern ST, Sternberg C, Stork B, Strålfors P, Subauste CS, Sui X, Sulzer D, Sun J, Sun SY, Sun ZJ, Sung JJ, Suzuki K, Suzuki T, Swanson MS, Swanton C, Sweeney ST, Sy LK, Szabadkai G, Tabas I, Taegtmeyer H, Tafani M, Takács-Vellai K, Takano Y, Takegawa K, Takemura G, Takeshita F, Talbot NJ, Tan KS, Tanaka K, Tanaka K, Tang D, Tang D, Tanida I, Tannous BA, Tavernarakis N, Taylor GS, Taylor GA, Taylor JP, Terada LS, Terman A, Tettamanti G, Thevissen K, Thompson CB, Thorburn A, Thumm M, Tian F, Tian Y, Tocchini-Valentini G, Tolkovsky AM, Tomino Y, Tönges L, Tooze SA, Tournier C, Tower J, Towns R, Trajkovic V, Travassos LH, Tsai TF, Tschan MP, Tsubata T, Tsung A, Turk B, Turner LS, Tyagi SC, Uchiyama Y, Ueno T, Umekawa M, Umemiya-Shirafuji R, Unni VK, Vaccaro MI, Valente EM, Van den Berghe G, van der Klei IJ, van Doorn W, van Dyk LF, van Egmond M, van Grunsven LA, Vandenabeele P, Vandenberghe WP, Vanhorebeek I, Vaquero EC, Velasco G, Vellai T, Vicencio JM, Vierstra RD, Vila M, Vindis C, Viola G, Viscomi MT, Voitsekhovskaja OV, von Haefen C, Votruba M, Wada K, Wade-Martins R, Walker CL, Walsh CM, Walter J, Wan XB, Wang A, Wang C, Wang D, Wang F, Wang F, Wang G, Wang H, Wang HG, Wang HD, Wang J, Wang K, Wang M, Wang RC, Wang X, Wang X, Wang YJ, Wang Y, Wang Z, Wang ZC, Wang Z, Wansink DG, Ward DM, Watada H, Waters SL, Webster P, Wei L, Weihl CC, Weiss WA, Welford SM, Wen LP, Whitehouse CA, Whitton JL, Whitworth AJ, Wileman T, Wiley JW, Wilkinson S, Willbold D, Williams RL, Williamson PR, Wouters BG, Wu C, Wu DC, Wu WK, Wyttenbach A, Xavier RJ, Xi Z, Xia P, Xiao G, Xie Z, Xie Z, Xu DZ, Xu J, Xu L, Xu X, Yamamoto A, Yamamoto A, Yamashina S, Yamashita M, Yan X, Yanagida M, Yang DS, Yang E, Yang JM, Yang SY, Yang W, Yang WY, Yang Z, Yao MC, Yao TP, Yeganeh B, Yen WL, Yin JJ, Yin XM, Yoo OJ, Yoon G, Yoon SY, Yorimitsu T, Yoshikawa Y, Yoshimori T, Yoshimoto K, You HJ, Youle RJ, Younes A, Yu L, Yu L, Yu SW, Yu WH, Yuan ZM, Yue Z, Yun CH, Yuzaki M, Zabirnyk O, SilvaZacarin E, Zacks D, Zacksenhaus E, Zaffaroni N, Zakeri Z, Zeh HJ 3rd, Zeitlin SO, Zhang H, Zhang HL, Zhang J, Zhang JP, Zhang L, Zhang L, Zhang MY, Zhang XD, Zhao M, Zhao YF, Zhao Y, Zhao ZJ, Zheng X, Zhivotovsky B, Zhong Q, Zhou CZ, Zhu C, Zhu WG, Zhu XF, Zhu X, Zhu Y, Zoladek T, Zong WX, Zorzano A, Zschocke J, Zuckerbraun B. Guidelines for the use and interpretation of assays for monitoring autophagy. Autophagy 2012;8:445-544.

59. Jin S, DiPaola RS, Mathew R, White E. Metabolic catastrophe as a means to cancer cell death. J Cell Sci 2007;120:379-83.

60. Mathew R, Karantza-Wadsworth V, White E. Role of autophagy in cancer. Nat Rev Cancer 2007;7:961-7.

61. Zhu K, Dunner K Jr, McConkey DJ. Proteasome inhibitors activate autophagy as a cytoprotective response in human prostate cancer cells. Oncogene 2010;29:451-62. 
62. Mathew R, Kongara S, Beaudoin B, Karp CM, Bray K, Degenhardt K, Chen G, Jin S, White E. Autophagy suppresses tumor progression by limiting chromosomal instability. Genes Dev 2007;21:1367-81.

63. Levine B, Klionsky DJ. Development by self-digestion: molecular mechanisms and biological functions of autophagy. Dev Cell 2004;6:463-77.

64. Degenhardt K, Mathew R, Beaudoin B, Bray K, Anderson D, Chen G, Mukherjee C, Shi Y, Gélinas C, Fan Y, Nelson DA, Jin S, White E. Autophagy promotes tumor cell survival and restricts necrosis, inflammation, and tumorigenesis. Cancer Cell 2006;10:51-64.

65. Palumbo S, Comincini S. Autophagy and ionizing radiation in tumor: the "survive or not survive" dilemma. $J$ Cell Physiol 2013;228:1-8.

66. Qu X, Yu J, Bhagat G, Furuya N, Hibshoosh H, Troxel A, Rosen J, Eskelinen EL, Mizushima N, Ohsumi Y, Cattoretti G, Levine B. Promotion of tumorigenesis by heterozygous disruption of the beclin 1 autophagy gene. J Clin Invest 2003;112:1809-20.

67. Dalby KN, Tekedereli I, Lopez-Berestein G, Ozpolat B. Targeting the prodeath and prosurvival functions of autophagy as novel therapeutic strategies in cancer. Autophagy 2010;6:322-9.

68. Kok K, Geering B, Vanhaesebroeck B. Regulation of phosphoinositide 3-kinase expression in health and disease. Trends Biochem Sci 2009;34:115-27.

69. Chalhoub N, Baker SJ. PTEN and the PI3-kinase pathway in cancer. Ann Rev Pathol 2009;4:127-50.

70. Markman B, Dienstmann R, Tabernero J. Targeting the PI3K/Akt/mTOR pathway--beyond rapalogs. Oncotarget 2010;1:530-43.

71. Davies BR, Greenwood H, Dudley P, Crafter C, Yu DH, Zhang J, Li J, Gao B, Ji Q, Maynard J, Ricketts SA, Cross D, Cosulich S, Chresta CC, Page K, Yates J, Lane C, Watson R, Luke R, Ogilvie D, Pass M. Preclinical pharmacology of AZD5363, an inhibitor of AKT: pharmacodynamics, antitumor activity, and correlation of monotherapy activity with genetic background. Mol Cancer Ther 2012;11:873-87.

72. Lamoureux F, Thomas C, Crafter C, Kumano M, Zhang F, Davies BR, Gleave ME, Zoubeidi A. Blocked autophagy using lysosomotropic agents sensitizes resistant prostate tumor cells to the novel Akt inhibitor AZD5363. Clin Cancer Res 2013;19:833-44.

73. Romanelli F, Smith KM, Hoven AD. Chloroquine and hydroxychloroquine as inhibitors of human immunodeficiency virus (HIV-1) activity. Curr Pharm Des 2004;10:2643-8.

74. Maclean KH, Dorsey FC, Cleveland JL, Kastan MB. Targeting lysosomal degradation induces p53-dependent cell death and prevents cancer in mouse models of lymphomagenesis. J Clin Invest 2008;118:79-88.

75. Amaravadi RK, Lippincott-Schwartz J, Yin XM, Weiss WA, Takebe N, Timmer W, DiPaola RS, Lotze MT, White E. Principles and current strategies for targeting autophagy for cancer treatment. Clin Cancer Res 2011;17:654-66.

76. Maycotte P, Aryal S, Cummings CT, Thorburn J, Morgan MJ, Thorburn A. Chloroquine sensitizes breast cancer cells to chemotherapy independent of autophagy. Autophagy 2012;8:200-12.

77. Hu C, Solomon VR, Ulibarri G, Lee H. The efficacy and selectivity of tumor cell killing by Akt inhibitors are substantially increased by chloroquine. Bioorg Med Chem 2008;16:7888-93.

78. Fan QW, Cheng C, Hackett C, Feldman M, Houseman BT, Nicolaides T, Haas-Kogan D, James CD, Oakes SA, Debnath J, Shokat KM, Weiss WA. Akt and autophagy cooperate to promote survival of drug-resistant glioma. Sci Signal 2010;3:ra81.

79. Gibbs A, Schwartzman J, Deng V, Alumkal J. Sulforaphane destabilizes the androgen receptor in prostate cancer cells by inactivating histone deacetylase 6. Proc Natl Acad Sci U S A 2009;106:16663-8.

80. Vyas AR, Hahm ER, Arlotti JA, Watkins S, Stolz DB, Desai D, Amin S, Singh SV. Chemoprevention of prostate cancer by D,Lsulforaphane is augmented by pharmacological inhibition of autophagy. Cancer Res 2013;73:5985-95.

81. Chiavarina B, Whitaker-Menezes D, Martinez-Outschoorn UE, Witkiewicz AK, Birbe R, Howell A, Pestell RG, Smith J, Daniel R, Sotgia F, Lisanti MP. Pyruvate kinase expression (PKM1 and PKM2) in cancer-associated broblasts drives stromal nutrient production and tumor growth. Cancer Biol Ther 2011;12:1101-13.

82. Ahmad F, Dixit D, Joshi SD, Sen E. G9a inhibition induced PKM2 regulates autophagic responses. Int J Biochem Cell Biol 2016;78:87-95.

83. Roy A, Ramalinga M, Kim OJ, Chijioke J, Lynch S, Byers S, Kumar D. Multiple roles of RARRES1 in prostate cancer: autophagy induction and angiogenesis inhibition. PLoS One 2017;12:e0180344.

84. Zeng J, Liu W, Fan YZ, He DL, Li L. PrLZ increases prostate cancer docetaxel resistance by inhibiting LKB1/AMPK-mediated autophagy. Theranostics 2018;8:109-23.

85. Bristol ML, Emery SM, Maycotte P, Thorburn A, Chakradeo S, Gewirtz DA. Autophagy inhibition for chemosensitization and radiosensitization in cancer: do the preclinical data support this therapeutic strategy? J Pharmacol Exp Ther 2013;344:544-52.

86. He Z, Mangala LS, Theriot CA, Rohde LH, Wu H, Zhang Y. Cell killing and radiosensitizing effects of atorvastatin in PC 3 prostate cancer cells. J Radiat Res 2012;53:225-33.

87. Yang ZJ, Chee CE, Huang S, Sinicrope FA. The role of autophagy in cancer: therapeutic implications. Mol Cancer Ther 2011;10:1533-41.

88. Schoenlein PV, Periyasamy-Thandavan S, Samaddar JS, Jackson WH, Barrett JT. Autophagy facilitates the progression of ERalphapositive breast cancer cells to antiestrogen resistance. Autophagy 2009;5:400-3.

89. Kaini RR, Hu CA. Synergistic killing effect of chloroquine and androgen deprivation in LNCaP cells. Biochem Biophys Res Commun 2012;425:150-6.

90. Bennett HL, Stockley J, Fleming JT, Mandal R, O’Prey J, Ryan KM, Robson CN, Leung HY. Does androgen-ablation therapy (AAT) associated autophagy have a pro-survival effect in LNCaP human prostate cancer cells? BJU Int 2013;111:672-82.

91. Cheong H, Lu C, Lindsten T, Thompson CB. Therapeutic targets in cancer cell metabolism and autophagy. Nat Biotechnol 2012;30:671-8.

92. Xing N, Chen Y, Mitchell SH, Young CY. Quercetin inhibits the expression and function of the androgen receptor in LNCaP prostate 
cancer cells. Carcinogenesis 2001;22:409-14.

93. Parikh A, Childress C, Deitrick K, Lin Q, Rukstalis D, Yang W. Statin-induced autophagy by inhibition of geranylgeranyl biosynthesis in prostate cencar PC3 cells. Prostate 2010;70:971-81.

94. Chhipa RR, Wu Y, Ip C. AMPK-mediated autophagy is a survival mechanism in androgen-dependent prostate cancer cells subjected to androgen deprivation and hypoxia. Cell Signal 2011;23:1466-72.

95. Jiang Q, Yeh S, Wang X, Xu D, Zhang Q, Wen X, Xia S, Chang C. Targeting androgen receptor leads to suppression of prostate cancer via induction of autophagy. J Urol 2012;188:1361-8.

96. Jain RK, Safabakhsh N, Sckell A, Chen Y, Jiang P, Benjamin L, Yuan F, Keshet E. Endothelial cell death, angiogenesis, and microvascular function after castration in an androgen-dependent tumor: role of vascular endothelial growth factor. Proc Natl Acad Sci U S A 1998;95:10820-5.

97. Chhipa RR, Wu Y, Mohler JL, Ip C. Survival advantage of AMPK activation to androgen-independent prostate cancer cells during energy stress. Cell Signal 2010;221554-61.

98. Meijer AJ, Codogno P. AMP-activated protein kinase and autophagy. Autophagy 2007;3:238-40.

99. Park HU, Suy S, Danner M, Dailey V, Zhang Y, Li H, Hyduke DR, Collins BT, Gagnon G, Kallakury B, Kumar D, Brown ML, Fornace A, Dritschilo A, Collins SP. AMP-activated protein kinase promotes human prostate cancer cell growth and survival. Mol Cancer Ther 2009;8:733-41.

100. Scherz-Shouval R, Shvets E, Fass E, Shorer H, Gil L, Elazar Z. Reactive oxygen species are essential for autophagy and specifically regulate the activity of Atg4. EMBO J 2007;26:1749-60.

101. Lin H, Lu JP, Laflamme P, Qiao S, Shayegan B, Bryskin I, Monardo L, Wilson BC, Singh G, Pinthus JH. Inter-related in vitro effects of androgens, fatty acids and oxidative stress in prostate cancer: a mechanistic model supporting prevention strategies. Int J Oncol 2010;37:761-6.

102. Ray PD, Huang BW, Tsuji Y. Reactive oxygen species (ROS) homeostasis and redox regulation in cellular signaling. Cell Signal 2012;24:981-90.

103. White E, DiPaola RS. The double-edged sword of autophagy modulation in cancer. Clin Cancer Res 2009;15:5308-16.

104. Tang DG, Porter AT. Target to apoptosis: a hopeful weapon for prostate cancer. Prostate 1997;32:284-93.

105. Saleem A, Dvorzhinski D, Santanam U, Mathew R, Bray K, Stein M, White E, DiPaola RS. Effect of dual inhibition of apoptosis and autophagy in prostate cancer. Prostate 2012;72:1374-81.

106. Nakajima Y, DelliPizzi AM, Mallouh C, Ferreri NR. TNF-mediated cytotoxicity and resistance in human prostate cancer cell lines. Prostate 1996;29:296-302.

107. Giampietri C, Petrungaro S, Padula F, D’Alessio A, Marini ES, Facchiano A, Filippini A, Ziparo E. Autophagy modulators sensitize prostate epithelial cancer cell lines to TNF-alpha-dependent apoptosis. Apoptosis 2012;17:1210-22.

108. He W, Wang Q, Xu J, Xu X, Padilla MT, Ren G, Gou X, Lin Y. Attenuation of TNFSF10/TRAIL induced apoptosis by an autophagic survival pathway involving TRAF2- and RIPK1/RIP1-mediated MAPK8/JNK activation. Autophagy 2012;8:1811-21.

109. Shin S, Jing K, Jeong S, Kim N, Song KS, Heo JY, Park JH, Seo KS, Han J, Park J, Kweon GR, Park SK, Wu T, Hwang BD, Lim K. The omega-3 polyunsaturated fatty acid DHA induces simultaneous apoptosis and autophagy via mitochondrial ROS-mediated AktmTOR signaling in prostate cancer cells expressing mutant p53. Biomed Res Int 2013;2013:568671.

110. Xu AH, Hu ZM, Qu JB, Liu SM, Syed AK, Yuan HQ, Lou HX. Cyclic bisbibenzyls induce growth arrest and apoptosis of human prostate cancer PC3 cells. Acta Pharmacol Sin 2010;31:609-15.

111. Jiang H, Sun J, Xu Q, Liu Y, Wei J, Young CY, Yuan H, Lou H. Marchantin M: a novel inhibitor of proteasome induces autophagic cell death in prostate cancer cells. Cell Death Dis 2013;4:e761.

112. Chang YM, Kung HJ, Evans CP. Nonreceptor tyrosine kinases in prostate cancer. Neoplasia 2007;9:90-100.

113. Kung HJ. Targeting tyrosine kinases and autophagy in prostate cancer. Horm Cancer 2011;2:38-46.

114. Kim LC, Song L, Haura EB. Src kinases as therapeutic targets for cancer. Nat Rev Clin Oncol 2009;6:587-95.

115. Saad F. Src as a therapeutic target in men with prostate cancer and bone metastases. BJU Int 2009;103:434-40.

116. Wu Z, Chang PC, Yang JC, Chu CY, Wang LY, Chen NT, Ma AH, Desai SJ, Lo SH, Evans CP, Lam KS, Kung HJ. Autophagy blockade sensitizes prostate cancer cells towards src family kinase inhibitors. Genes Cancer 2010;1:40-9.

117. Guo W, Liu R, Bhardwaj G, Yang JC, Changou C, Ma AH, Mazloom A, Chintapalli S, Xiao K, Xiao W, Kumaresan P, Sanchez E, Yeh CT, Evans CP, Patterson R, Lam KS, Kung HJ. Targeting Btk/Etk of prostate cancer cells by a novel dual inhibitor. Cell Death Dis 2014;5:e1409.

118. Qui Y, Robinson D, Pretlow TG, Kung HJ. Etk/Bmx, a tyrosin kinase with a pleckstrin-homology domain, is an effectorof phosphatidylinositol 3'-kinase and is involved in interleukin 6-induced neuroendocrine differentiation of prostate cancer cells. Proc Natl Acad Sci U S A 1998;95:3644-9.

119. Jiang T, Guo Z, Dai B, Kang M, Ann DK, Kung HJ, Qui Y. Bi-directional regulation between tyrosine kinase Etk/BMX and tumor suppressor p53 in response to DNA damage. J Biol Chem 2004;279:50181-9.

120. Wu YM, Huang CL, Kung HJ, Huang CY. Proteolytic activation of ETK/Bmx tyrosine kinase by caspase. J Biol Chem 2001;276:17672-8.

121. Lee LF, Louie MC, Desai SJ, Yang J, Chen HW, Evans CP, Kung HJ. Interleukin-8 confers androgen-independent growth and migration of LNCaP: differential effects of tyrosine kinases Src and FAK. Oncogene 2004;23:2197-205.

122. Vallo S, Mani J, Stastny M, Makarević J, Juengel E, Tsaur I, Bartsch G, Haferkamp A, Blaheta RA. PXD101 potentiates hormonal therapy and prevents the onset of castration-resistant phenotype modulating androgen receptor, HSP90, and CRM1 in preclinical models of prostate cancer. Endocr Relat Cancer 2013;20:321-37. 
123. Long J, Zhao J, Yan Z, Liu Z, Wang N. Antitumor effects of a novel sulfur-containing hydroxamate histone deacetylase inhibitor H40. Int $J$ Cancer 2009;124:1235-44.

124. Patra N, De U, Kim TH, Lee YJ, Ahn MY, Kim ND, Yoon JH, Choi WS, Moon HR, Lee BM, Kim HS. A novel histone deacetylase (HDAC) inhibitor MHY219 induces apoptosis via up-regulation of androgen receptor expression in human prostate cancer cells. Biomed Pharmacother 2013;67:407-15.

125. Beaver LM, Yu TW, Sokolowski EI, Williams DE, Dashwood RH, Ho E. 3,3'-Diindolylmethane, but not indole-3-carbinol, inhibits histone deacetylase activity in prostate cancer cells. Toxicol Appl Pharmacol 2012;236:345-51.

126. Choi ES, Han G, Park SK, Lee K, Kim HJ, Cho SD, Kim HM. A248, a novel synthetic HDAC inhibitor, induces apoptosis through the inhibition of specificity protein 1 and its downstream proteins in human prostate cancer cells. Mol Med Rep 2013;8:195-200.

127. Vallo S, Mani J, Stastny M, Makarević J, Juengel E, Tsaur I, Bartsch G, Haferkamp A, Blaheta RA. The prostate cancer blocking potential of the histone deacetylase inhibitor LBH589 is not enhanced by the multi receptor tyrosine kinase inhibitor TKI258. Invest New Drugs 2013;31:265-72.

128. Hoang JJ, Baron S, Volle DH, Lobaccaro JM, Trousson A. Lipids, LXRs and prostate cancer: are HDACs a new link? Biochem Pharmacol 2013;86:168-74.

129. Tang X, Jia J, Li F, Liu W, Yang C, Jin B, Shi Q, Wang X, He D, Guo P. Salen-Mn compounds induces cell apoptosis in human prostate cancer cells through promoting AMPK activity and cell autophagy. Oncotarget 2017;8:86277-86. 